\title{
Sleep and Stress of Late Middle Age Males Who Are Forced to Live in Emergency Temporary Houses and Post-Earthquake Public Houses for a Long Period Due to the Fukushima Daiichi Nuclear Power Station Accident
}

\author{
Yuka Iwasa1, Yoshiyuki Muramatsu¹, Hagiko Aoki'1, Chikako Tomiyama², Tomoko Saito1, \\ Mayumi Nishikata1, Mieko Uchiyama1 \\ ${ }^{1}$ Department of Nursing, School of Health Sciences, Faculty of Medicine, Niigata University, Niigata, Japan \\ ${ }^{2}$ Department of Medical Technology, School of Health Sciences, Faculty of Medicine, Niigata University, Niigata, Japan \\ Email: iwasa@clg.niigata-u.ac.jp
}

How to cite this paper: Iwasa, Y., Muramatsu, Y., Aoki, H., Tomiyama, C., Saito, T., Nishikata, M. and Uchiyama, M. (2017) Sleep and Stress of Late Middle Age Males Who Are Forced to Live in Emergency Temporary Houses and Post-Earthquake Public Houses for a Long Period Due to the Fukushima Daiichi Nuclear Power Station Accident. Health, 9, 1787-1800.

https://doi.org/10.4236/health.2017.913130

Received: November 14, 2017

Accepted: December 9, 2017

Published: December 12, 2017

Copyright $\odot 2017$ by authors and Scientific Research Publishing Inc. This work is licensed under the Creative Commons Attribution International License (CC BY 4.0).

http://creativecommons.org/licenses/by/4.0/

\begin{abstract}
It has been revealed that prolonged shelter life caused by Fukushima Daiichi Nuclear Power Station accident in conjunction with the Great East Japan Earthquake influences sleep and mental health of the residents, and therefore its influence on their physical and emotional health has become a concern. Therefore, in this study, the authors aimed at clarifying actual situations of sleep and stress of middle age males living in shelters for a long period in each of emergency temporary houses and post-earthquake public houses. For 5 males who moved from emergency temporary houses to post-earthquake public houses, their objective and subjective sleep states were measured with Actigraph and PSQI, respectively. Furthermore, their objective and subjective stresses were measured with saliva stress biomarkers and GHQ28, respectively. Their data were analyzed by paired t-test. As result, in comparison between the life in the emergency temporary houses and post-earthquake public houses, significant variation was not recognized in their objective sleep states and saliva stress biomarkers though their subjective sleep and subjective stress were significantly worsened after moving to the post-earthquake public houses.
\end{abstract}

\section{Keywords}

Fukushima Daiichi Nuclear Power Station Accident, Emergency

Temporary House, Actigraph, Sleep, Mental Stress 


\section{Introduction}

A number of people are living as evacuees in emergency temporary houses (hereinafter called temporary house), leased houses, post-earthquake public houses (hereinafter called post-earthquake house) and so on even now, due to the Great East Japan Earthquake and Tokyo Electric Fukushima Daiichi Nuclear Power Station accident (hereinafter called nuclear disaster) in conjunction with it [1]. Temporary houses were usually closed within five years in the past disasters. Although it has been over six years since the disaster, 10,213 people in Fukushima (as of March 31, 2017) [2] are forced to live in temporary houses being concerned about uncertain prospects. Such a situation has never happened before. The number of deaths (as of March 31, 2017) related to the Great East Japan Earthquake reported by Reconstruction Agency is, among the 3 prefectures in Tohoku, 463 in Iwate, 926 in Miyagi, and 2147 in Fukushima [3]. The number is overwhelmingly high in Fukushima, and Fukushima is the only district where deaths related to the disaster have occurred even 5 or more years after the earthquake disaster. Moreover, "The total number of suicides related to the Great East Japan Earthquake" reported by the Office for Policy of Suicide Prevention of Ministry of Health, Labour and Welfare [4] is 56 in 2015, 4 years after the disaster, and by prefecture, 31 in Fukushima (55.4\%), 13 in Miyagi (23.2\%) and 12 in Iwate (21.4\%), suggesting that Fukushima accounts for majority. By gender, it is 37 in males (66.1\%) and 19 in women (33.9\%), suggesting that males account for over two-thirds. By age, it is 23 in 30 - 59 years old (41.1\%), indicating that the rate of late middle age males is high. It has been clarified from the past disasters [5] that life as an evacuee has an influence on psychosomatic health of the victims. In Japan, a number of investigations have been carried out since the Great Hanshin-Awaji Earthquake [6]. Large-scale health survey [7] [8] has been carried out for the Great East Japan Earthquake, and worsening of life habits such as drinking and smoking by evacuation life, weight gain, increase in the tendency toward depression and increase in the prevalence of sleep disorders have been reported. The investigation for 200 temporary housing residents in Fukushima has revealed that weight, BMI, abdominal circumference and HbA1C increased from before the earthquake disaster [9]. Moreover, according to the investigation performed by Fukushima Medical College in 2015 [10], the rate of residents with poor mental health states was $7.7 \%$, and this tendency was higher than that of residents of usual communities in Japan (3.0\%). In addition, according to the report of the local government of a village whose villagers all evacuate due to the nuclear disaster [11], significant increase in the rate of the residents having obesity, high blood pressure, diabetes mellitus and lipid abnormalities was seen after the earthquake disaster. Furthermore, significant increase in BMI, contraction phase, diastolic blood pressure, fasting blood sugar, LDL cholesterol, fasting triglyceride, AST, ALT and gamma-glutamyl transpeptidase and increase in their prevalence was recognized in males in particular. Moreover, in the above report [11], the cause of weight gain was examined and it has been re- 
vealed that although the variation of eating habit was not seen, the rate of the residents who had sufficient rest by sleep decreased. Therefore, the possibility that control of stress and sleep influences weight gain has been pointed out. In recent years, it has been indicated that insufficient sleep time and insomnia raises the onset risks of obese [12], hypertensive [13] glucose tolerance disorder [14], metabolic syndrome [15] and depression [16] and therefore influence of evacuation life of late middle age males on their physical and emotional health is a concern. The investigation for sleep of the victims were performed mainly by questionnaire for descriptive subjective evaluation based on self-report by the subjects and therefore the results may not correspond with those for objective sleep [17]. Studies on objective sleep of late middle age male victims have not been published so far and therefore it will be helpful in reconstruction aid to grasp the actual situation of the objective sleep and stress of late middle age males who are in their prime and assume an important role for the reconstruction. This time, aiming at clarifying how the long-term evacuation life caused by the nuclear station accident influence the sleep and stress of late middle age males, the authors measured objective sleep state, Objective stress conditions with Actigraph and noninvasive saliva stress biomarkers, respectively, and subjective sleep and stress by questionnaire.

\section{Purpose of Study}

The purpose of this study is to focus on sleep and stress of late middle age males spending evacuation life for a long period due to the nuclear disaster, and clarify actual situations of their life in temporal houses and post-earthquake houses.

\section{Methods}

\subsection{Study Design}

Observational, prospective study.

\subsection{Subject of the Study}

Late middle age males who suffered from by the accident of Fukushima Daiichi Nuclear Power Station and have evacuated to temporal houses due to the Great East Japan Earthquake.

The inclusion criteria is late middle age males who moved to post-earthquake public houses after living in emergency temporary housing, and the exclusion criteria is males who is taking medications that affect sleep (hypnotics, antidepressants, antipsychotics, etc.).

\subsection{Data Collection Period}

From December, 2015 to February, 2017.

\subsection{Approach}

For the purpose of grasping sleep and stress of the victims, the investigation was 
performed by using Actigraph (micro motion logger made by A.M.I), Japanese edition of the Pittsburgh Sleep Quality Index (hereinafter called PSQI), General Health Questionnaire 28 (hereinafter called GHQ28) and Saliva stress biomarker. ( $\alpha$-Amylase, Cortisol, Chromogranin A, s-IgA). The investigation at the time when they were living in the temporal houses (from December, 2015 to February; 57 - 59 months after the disaster) and in the post-earthquake houses (December, 2016 to February; 69 - 71 months after the disaster).

\subsubsection{Grasp of Sleep State}

Sleep Minutes (sleep time), Sleep Efficiency (sleep onset efficiency), Sleep Latency (sleep latency) and Wake after Sleep Onset (arousal time) were measured with Actigraph so as to grasp objective sleep state of the subjects [18]. Study subjects were requested to wear Actigraph on their wrists of non-dominant hands for 24 hours for five days including Saturday and Sunday. The collected data were analyzed with the special analysis software AW2, and the algorithm discriminant proposed by Cole [19] was used to evaluate arousal. The subjects were requested to fill in PSQI [20] while wearing Actigraph to grasp subjective sleep states of the subjects. PSQI is a self-administered questionnaire designed to measure quality of sleep, sleep time, sleep onset, sleep efficiency, sleep difficulty, use of sleep medication, troubles occurred in everyday life caused by drowsiness in daytime and so on, consisting of 18 question items with 7 subscales. In PSQI, higher scores indicate higher degrees of the sleep trouble.

\subsubsection{Grasp of Stress}

The subjects were requested to fill in GHQ28 [21] while wearing Actigraph to grasp subjective stress of them. GHQ28 consists of 28 question items with 4 subscales of physical symptoms, anxiety and insomnia, social disability and depression tendency. For recent mental health states, the answers "Not much" and "Not at all" were given 0 point and "Yes" and "Yes, frequently" were given 1 point and the evaluation was performed according to the total scores or each subscale.. The subjects with the total scores of over 6 points were judged as having some problems related to their mental health. For the physical symptoms, anxiety and insomnia of the subscale, the subjects were judged as having the symptoms when their scores are 2 points or more. For social disability and depression tendency, the subjects were judged as having the symptoms when their scores are 1 point or more. Moreover, for the purpose of evaluating objective stress of the subjects, the subjects were asked to sample their saliva, which can be sampled easily in a non-invasive manner, before bedtime and at the time of awakening everyday during the period in which the subjects wore Actigraph. $\alpha$-Amylase activity [22] in saliva as an index of acute stress reaction, Cortisol concentration [23] as an index of chronic stress, and Chromogranin A ( CgA) concentration [24] and salivary secretor immunoglobulin A (s-IgA) secretion rate [25] as an index of mental stress were measured. Oral swab (SOS) and preservation tubes were used for sampling. After collecting saliva, the samples were 
centrifuged, preserved at -80 degrees Celsius or less, and sent to Yanaihara Institute Inc. (Shizuoka) for examination. Salivary $\alpha$-Amylase Kinetic Enzyme Assay Kit (Salimetrics), YK241 Cortisol (Saliva) EIA Kit (Yanaihara Institute Inc.), YK070 Human Chromogranin A EIA kit (Yanaihara Institute Inc.) and YK280 Human s-IgA (Saliva) ELISA kit (YYanaihara Institute Inc.) were used for the examination.

\subsection{Analytical Method}

The paired t-test was used for comparison between the data obtained from temporary houses and those from post-earthquake houses. Furthermore, one sample $t$-test was used for comparison between the total GHQ28 point of average males shown in literature and the total GHQ point obtained in this study. $p$ values below 0.05 was regarded as significant. IBM SPSS ver. 24 for windows was used for all statistical analyses.

\subsection{Ethical Consideration}

This study was approved by the Ethical Committee of School of Medicine, Niigata University (authorization number 2324). Moreover, the study was performed in compliance with Ethical guideline for medical research targeting human subjects [26], Ethical guideline for investigative research targeting disaster victims [27] and Guideline for investigation on the Great East Japan Earthquake [28]. As an ethical consideration, the authors explained to the study subjects orally and in documents about the study goal, methods, right to participate and refuse by free will, privacy protection, personal information protection and so on. After data analyses, we explained about the results directly to the subjects each time.

\section{Results}

\subsection{Outline of Subjects (Table 1)}

Ten subjects were employed for the study. Five of the subjects who moved to post-earthquake houses and over 5 months ago were employed as subjects for the analyses performed in this study. The age of the 5 subjects was $53.8 \pm 8.4$ years old (average \pm standard deviation), 2 of whom work and 3 of whom took regular exercise 2 or 3 times a week. Furthermore, four of them lived with their families and 1 of them had taken antihypertensive drug after earthquake disaster. None of them took sleeping drug, antianxiety drug or antipsychotic drug, which might have an influence on their sleep. They lived in the temporary houses for the period from August to September, 2011. Average period of their life in the temporary houses was $53.8 \pm 1.1$ months and that of the post-earthquake houses was $5.4 \pm 0.6$ months.

\subsection{Objective Evaluation of Sleep by Actigraph (Table 2)}

Results obtained by Actigraph at the time of living in the temporary houses 
Table 1. Subjects' profile.

\begin{tabular}{|c|c|c|c|c|c|c|c|c|c|c|c|}
\hline & Age & $\begin{array}{c}\text { House } \\
\text { damage } \\
\text { caused by } \\
\text { earthquake }\end{array}$ & $\begin{array}{c}\text { evacuation } \\
\text { designated } \\
\text { zones where } \\
\text { he lived before } \\
\text { the earthquake }\end{array}$ & $\begin{array}{c}\text { Length of } \\
\text { stay at } \\
\text { Temporary } \\
\text { house }\end{array}$ & $\begin{array}{c}\text { Length of } \\
\text { stay at } \\
\text { Post-earthquake } \\
\text { public house }\end{array}$ & $\begin{array}{l}\text { family } \\
\text { to live } \\
\text { with }\end{array}$ & Employment & $\begin{array}{c}\text { Smoking } \\
\text { habit }\end{array}$ & $\begin{array}{c}\text { Drinking } \\
\text { habit }\end{array}$ & $\begin{array}{c}\text { Exercise } \\
\text { habit }\end{array}$ & $\begin{array}{c}\text { Internal } \\
\text { medicine } \\
\text { (after the } \\
\text { earthquake) }\end{array}$ \\
\hline A & $50 \mathrm{~s}$ & Damage & $\begin{array}{c}\text { Restricted } \\
\text { residence zone }\end{array}$ & 52 months & 5 months & Have & Employed & No & Have & Have & Nothing \\
\hline B & $40 \mathrm{~s}$ & No damege & $\begin{array}{l}\text { Evacuation order } \\
\text { cancellation } \\
\text { preparation zone }\end{array}$ & 54 months & 5 months & Have & Employed & Have & No & No & Nothing \\
\hline C & $40 \mathrm{~s}$ & Damage & $\begin{array}{c}\text { Restricted } \\
\text { residence zone }\end{array}$ & 54 months & 5 months & Have & No employed & No & No & Have & Nothing \\
\hline $\mathrm{D}$ & $60 \mathrm{~s}$ & No damege & $\begin{array}{l}\text { Evacuation order } \\
\text { cancellation } \\
\text { preparation zone }\end{array}$ & 54 months & 6 months & No & No employed & No & Have & Have & $\begin{array}{c}\text { antihypertensive } \\
\text { drug }\end{array}$ \\
\hline $\mathrm{E}$ & $60 \mathrm{~s}$ & No damege & $\begin{array}{l}\text { Evacuation order } \\
\text { cancellation } \\
\text { preparation zone }\end{array}$ & 55 months & 6 months & Have & No employed & No & Have & No & Nothing \\
\hline
\end{tabular}

Table 2. Objective sleep evaluation by Actigraph at the time of living in emergency temporary house and post-earthquake public house $(n=5)$.

\begin{tabular}{cccccc}
\hline & \multicolumn{2}{c}{$\begin{array}{c}\text { Emergency } \\
\text { temporary house }\end{array}$} & \multicolumn{2}{c}{$\begin{array}{c}\text { Post-earthquake } \\
\text { public house }\end{array}$} & S-value \\
\cline { 2 - 5 } & Average & Standard deviation & Average & Standard deviation & \\
\hline Sleep Minutes (min) & 338.5 & 124.8 & 318.8 & 119.8 & 0.267 \\
Sleep Efficiency (\%) & 87.5 & 18.5 & 90.5 & 9.2 & 0.613 \\
Sleep Latency (min) & 75.7 & 63.4 & 82.0 & 110.9 & 0.847 \\
Wake after Sleep Onset (min) & 42.1 & 54.1 & 25.9 & 19.2 & 0.486 \\
\hline
\end{tabular}

Paired t test $(p<0.05)$.

(mean \pm SD) revealed that Sleep Minutes, Sleep Efficiency, Sleep Latency and Wake after Sleep Onset were $338.5 \pm 124.8,87.5 \pm 18.5 \%, 75.7 \pm 63.4$ and $42.1 \pm$ 54.1, respectively. Results obtained by Actigraph at the time of living in the post-earthquake houses (mean \pm SD) revealed that Sleep Minutes, Sleep Efficiency, Sleep Latency and Wake after Sleep Onset were $318.8 \pm 119.8,90.5 \pm$ $9.2 \%, 82.0 \pm 110.9$ and $25.9 \pm 19.2$, respectively. There were no significant differences between the results from the temporary houses and the post-earthquake houses.

\subsection{Subjective Evaluation of Sleep by PSQI (Table 3)}

Results of PSQI obtained from the temporary houses (mean $\pm \mathrm{SD}$ ) revealed that the total PSQI points were $4.0 \pm 1.4$ points. As for the subscale, Quality of Sleep, Sleep Onset, Sleep Minutes, Sleep Efficiency, Difficulty Sleeping, Use of Sleep Medication and Difficulty Staying Awake in Daytime were $1.2 \pm 0.4$ pts, $0.8 \pm 0.8$ pts, 
Table 3. Subjective sleep evaluation by PSQI at the time of living in emergency temporary house and post-earthquake public house $(n=5)$.

\begin{tabular}{cccccc}
\hline & \multicolumn{2}{c}{$\begin{array}{c}\text { Emergency } \\
\text { temporary house }\end{array}$} & $\begin{array}{c}\text { Post-earthquake } \\
\text { public house }\end{array}$ & \\
\cline { 2 - 5 } & Average & $\begin{array}{c}\text { Standard } \\
\text { deviation }\end{array}$ & $\begin{array}{c}\text { Average } \\
\text { Standard } \\
\text { deviation }\end{array}$ & \\
Total PSQI score & 4.0 & 1.4 & 5.0 & 2.1 & 0.089 \\
Subscale & & & & & \\
Sleep Quality & 1.2 & 0.4 & 1.2 & 0.4 & - \\
Sleep Onset Time & 0.8 & 0.8 & 1.0 & 1.4 & 0.704 \\
Sleep Minutes & 1.0 & 0.0 & 1.2 & 0.4 & 0.374 \\
Sleep Efficiency & 0.0 & 0.0 & 0.2 & 0.4 & 0.374 \\
Difficulty sleeping & 0.4 & 0.5 & 1.0 & 0.0 & 0.070 \\
Use of sleep medication & 0.0 & 0.0 & 0.0 & 0.0 & - \\
Difficulty staying awake in daytime & 0.6 & 0.5 & 0.4 & 0.5 & 0.374 \\
\hline
\end{tabular}

Paired t test $(p<0.05)$.

$1.0 \pm 0.0 \mathrm{pts}, 0.0 \pm 0.0 \mathrm{pts}, 0.4 \pm 0.5 \mathrm{pts}, 0.0 \pm 0.0 \mathrm{pts}$ and $0.6 \pm 0.5 \mathrm{pts}$, respectively. Results of PSQI obtained from the post-earthquake houses revealed that the total PSQI points were $5.0 \pm 2.1$ points. As for the subscale, Quality of Sleep, Sleep Onset, Sleep Minutes, Sleep Efficiency, Difficulty Sleeping, Use of Sleep Medication and Difficulty Staying Awake in Daytime were $1.2 \pm 0.4$ pts, $1.0 \pm 1.4$ pts, $1.2 \pm 0.4$ pts, $0.2 \pm 0.4$ pts, $1.0 \pm 0.0$ pts, $0.0 \pm 0.0$ pts and $0.4 \pm 0.5$ pts, respectively. There were no significant differences between the results from the temporary houses and the post-earthquake houses. However, the total PSQI points $(p=0.089)$ and Difficulty Sleeping of the subscale $(p=0.070)$ were higher for the post-earthquake houses.

\subsection{Objective Stress Evaluation by Saliva Stress Biomarker (Table 4)}

Results of saliva stress biomarker obtained from the temporary houses (mean \pm $\mathrm{SD}$ ) revealed that the $\alpha$ Amylase activity was $167.936 \pm 46.424 \mathrm{U} / \mathrm{mL}$ before bedtime and $107.699 \pm 68.908 \mathrm{U} / \mathrm{mL}$ at the time of awakening. Moreover, Cortisol concentration was $0.047 \pm 0.033 \mu \mathrm{g} / \mathrm{dL}$ before bedtime and $0.350 \pm 0.264 \mu \mathrm{g} / \mathrm{dL}$ at the time of awakening. $\mathrm{CgA}$ (protein correction value) was $5.802 \pm 0.942$ $\mathrm{pmol} / \mathrm{mg}$ before bedtime and $0.443-0.140 \mathrm{pmol} / \mathrm{mg}$ at the time of wakening. IgA secretion rate was $14.973-8.197 \mu \mathrm{g} / \mathrm{min}$ before bedtime and $99.686 \pm 73.488$ $\mu \mathrm{g} / \mathrm{min}$ at the time of wakening. Results of saliva stress biomarker obtained from the temporary houses (mean $\pm \mathrm{SD}$ ) revealed that the $\alpha$ Amylase activity was $260.038 \pm 217.049 \mathrm{U} / \mathrm{mL}$ before bedtime and $134.742 \pm 128.269 \mathrm{U} / \mathrm{mL}$ at the time of awakening. Moreover, Cortisol concentration was $0.049 \pm 0.020 \mu \mathrm{g} / \mathrm{dL}$ before bedtime and $0.407 \pm 0.266 \mu \mathrm{g} / \mathrm{dL}$ at the time of awakening. $\mathrm{CgA}$ (protein correction value) was $5.713 \pm 2.534 \mathrm{pmol} / \mathrm{mg}$ before bedtime and $10.500 \pm 4.896$ 
Table 4. Objective sleep evaluation by stress biomarker at the time of living in emergency temporary house and post-earthquake public house $(n=5)$.

\begin{tabular}{|c|c|c|c|c|c|}
\hline \multirow{2}{*}{ Analysis item } & \multicolumn{2}{|c|}{$\begin{array}{c}\text { Emergency } \\
\text { temporary house }\end{array}$} & \multicolumn{2}{|c|}{$\begin{array}{l}\text { Post-earthquake } \\
\text { public house }\end{array}$} & \multirow{2}{*}{$p$-value } \\
\hline & Average & $\begin{array}{l}\text { Standard } \\
\text { deviation }\end{array}$ & Average & $\begin{array}{l}\text { Standard } \\
\text { deviation }\end{array}$ & \\
\hline \multicolumn{6}{|l|}{ aAmylase activity } \\
\hline Before bedtime $(\mathrm{U} / \mathrm{mL})$ & 167.936 & 46.424 & 260.038 & 217.049 & 0.333 \\
\hline At the time of awakening $(\mathrm{U} / \mathrm{mL})$ & 107.699 & 68.908 & 134.742 & 128.269 & 0.421 \\
\hline \multicolumn{6}{|l|}{ Cortisol concentration } \\
\hline Before bedtime $(\mu \mathrm{g} / \mathrm{dL})$ & 0.047 & 0.033 & 0.049 & 0.020 & 0.925 \\
\hline At the time of awakening $(\mu \mathrm{g} / \mathrm{dL})$ & 0.350 & 0.264 & 0.407 & 0.266 & 0.398 \\
\hline \multicolumn{6}{|l|}{ Chromogranin A (protein correction value) } \\
\hline Before bedtime (pmol/mg) & 5.802 & 0.942 & 5.713 & 2.534 & 0.951 \\
\hline At the time of awakening $(\mathrm{pmol} / \mathrm{mg})$ & 9.443 & 2.140 & 10.500 & 4.896 & 0.719 \\
\hline \multicolumn{6}{|l|}{ SIgA secretion rate } \\
\hline Before bedtime ( $\mu \mathrm{g} / \mathrm{min})$ & 114.973 & 58.197 & 138.104 & 69.022 & 0.252 \\
\hline At the time of awakening $(\mu \mathrm{g} / \mathrm{min})$ & 199.686 & 73.488 & 629.722 & 883.165 & 0.313 \\
\hline
\end{tabular}

Paired t test $(p<0.05)$.

$\mathrm{pmol} / \mathrm{mg}$ at the time of awakening. sIgA secretion rate was It was $138.104 \pm$ $69.022 \mu \mathrm{g} / \mathrm{min}$ before bedtime and $629.722 \pm 883.165 \mu \mathrm{g} / \mathrm{min}$ at the time of awakening. There were no significant differences between the results from the temporary houses and the post-earthquake houses.

\subsection{Subjective Stress Evaluation by GHQ28 (Table 5)}

The total GHQ28 score (mean \pm SD) obtained from the temporary houses was $2.4 \pm 2.2$ points. As for subscale, Physical Symptoms, Anxiety and Insomnia, Social Disability and Depression Tendency were $0.4 \pm 0.5$ pts, $1.4 \pm 1.5$ pts, $0.6 \pm$ 0.9 pts and $0.0 \pm 0.0$ pts, respectively. The total GHQ28 score (mean \pm SD) obtained from the post-earthquake houses was $6.2 \pm 3.4$ points. As for subscale, Physical Symptoms, Anxiety and Insomnia, Social Disability and Depression Tendency were $2.4 \pm 1.8$ pts, $3.0 \pm 2.0$ pts, $0.8 \pm 1.1$ pts and $0.0 \pm 0.0$ pts, respectively. The total score and anxiety and insomnia of the subscale exceeded the cutoff point. Comparing the results from temporary houses and those from the post-earthquake houses, the GHQ28 score $(p=0.030)$ and Physical Symptoms of the subscale $(p=0.047)$ were higher for the post-earthquake houses. Further, Anxiety and Insomnia of the subscale $(p=0.078)$ was also higher for the post-earthquake houses. The total GHQ28 score [21] was $2.89 \pm 2.00$. The result of one-sample t-test revealed that there were no significant differences in the total GHQ28 score of the temporary houses while on the other hand the total GHQ28 score of the post-earthquake houses was high $(p=0.094)$. 
Table 5. Subjective stress evaluation by GHQ28 at the time of living in emergency temporary house and post-earthquake public house $(n=5)$.

\begin{tabular}{cccccc}
\hline & \multicolumn{2}{c}{ Emergency temporary house } & \multicolumn{2}{c}{ Post-earthquake public house } & \multirow{2}{*}{$p$ value } \\
\cline { 2 - 5 } & Average & Standard deviation & Average & Standard deviation & \\
\hline Total scoe & 2.40 & 2.19 & 6.20 & 3.42 & 0.030 \\
Subscale & & & & & \\
Physical symptom & 0.40 & 0.55 & 2.40 & 1.82 & 0.047 \\
Anxiety and insomnia & 1.40 & 1.52 & 3.00 & 2.00 & 0.078 \\
Social disability & 0.60 & 0.89 & 0.80 & 1.10 & 0.778 \\
Depression tendency & 0.00 & 0.00 & 0.00 & 0.00 & - \\
\hline
\end{tabular}

Paired t test $(p<0.05)$.

\section{Discussion}

\subsection{Sleep of Late Middle Age Males Spending Evacuation Life for a Long Period}

Results of objective measurement of sleep by Actigrap revealed that there were no significant changes between the temporary houses and the post-earthquake houses for each item of Sleep Minutes, Sleep Efficiency, Sleep Latency and Wake after Sleep Onset. According to the data of 3577 healthy subjects obtained from 65 papers, for which nocturnal objective sleep had been investigated by electroencephalogram, Sleep Minutes of 50-year-old males were approximately 400 minutes, Sleep Efficiency was 87\% and Sleep Latency was approximately $17 \mathrm{mi}$ nutes. Furthermore, Wake after Sleep Onset is approximately around 30 minutes [29]. Although they cannot be compared statistically, the possibility that Wake after Sleep Onset of the male victims at the time of living in the temporary houses possibly increased more than that of the general late middle age males has been indicated. Since the temporary houses are built by a simple construction method and consist of simple structures as a temporary house where disaster victims live until they move to rebuilt houses or post-earthquake houses, they are basically small and sound insulation is not sufficient, which forces the residents to live with noise from the neighbors [30]. Considering the fact that Wake after Sleep Onset decreased at the time of living in the post-earthquake houses for which livability was improved, it is possible that arousal increased by the sound of the housemates and the neighbors when they lived in the temporary houses. Since the life in the temporary houses as a temporary shelter may adversely affect sleep of the residents, it is desired to support the residents so that they can move to post-earthquake houses or their own houses as soon as possible. Since changes in subjective sleep were observed in the total PSQI score ( $p=$ $0.089)$ and Difficulty Sleeping of the subscale $(p=0.070)$, the possibility that the subjective sleep at the time of living in the post-earthquake houses residence worsened has been indicated. According to the large-scale investigation [31] for victims of the Great East Japan Earthquake performed in Miyagi, the rate of suspected sleep disorders (more than 6 points in Athens Insomnia Scale) increased in the subjects who moved to new houses and those who moved to the 
post-earthquake houses. It has been reported that in the Great Hanshin-Awaji Earthquake, the victims suffered from stress that newly occurred due to variation in physical and human environmental factors after they moved from temporary houses to post-earthquake houses [32]. Since the time period for which the data for this study were collected was only 5 months after the subjects moved to the post-earthquake houses, the fact that subject were not used to change in the physical and human environment after moving may have worsened their subjective sleep. It is necessary to measure sleep at regular intervals and grasp changes in the sleep of late middle age males who are the victims of the disaster, and to provide support to them in the future.

\subsection{Stress of Late Middle Age Males Spending Evacuation Life for a Long Period}

The results of evaluation of objective stress with saliva stress biomarkers have revealed that there are no significant differences between temporal houses and post-earthquake houses. However, as for GHQ28, which was used as a subjective stress index, the total GHQ28 score obtained at the time of living in the post-earthquake houses and Physical Symptoms, Anxiety and Insomnia of the subscale exceeded the cutoff point. Furthermore, it has been clarified that the mental health of the subjects at the time of living in the post-earthquake houses was higher than that of general males, and was significantly worse than that at the time of living in the temporal houses. From the past disasters, it has been revealed that GHQ is significantly improved with time after disasters. The investigation carried out for the victims of eruptions of Mt. Fugen in Unzen [33] revealed that the rates of high GHQ30 scorers were $66.1 \%$ at 6 months, $50.8 \%$ at 12 months, $55.6 \%$ at 24 months, $45.6 \%$ at 44 months and $29.4 \%$ at 102 months after the disaster suggesting that it was significantly improved with time. Moreover, the investigation for the victims of the Okushiri Tsunami Disaster [34] revealed that the rates of the high GHQ28 scorer (6 points or more) were $76.6 \%$ at 10 months, $68.0 \%$ at 27 months, $57.2 \%$ at 51 months and $54.6 \%$ at 74 months after the disaster suggesting that it was also significantly improved with time. In this study, the authors have not grasped changes in mental health of the victims for the period from right after the disaster to 56th month. However, comparison between the mental health at 56 months and 78 months after the disaster has suggested that mental health was significantly worsened. The large-scale investigation performed in Miyagi described above [31] revealed that the rate of the victims with high psychological distress increased once after they had moved to post-earthquake houses, and then decreased down to the rate that is same as that at the time when they had moved to temporary houses. Norris, F. H. [5] has pointed out that the temporal or permanent relocation affects relations with neighborhood and causes interpersonal tension and conflict, which eventually ruins the social network and causes secondary negative psychological social impacts. The investigation of the Great Hanshin-Awaji Earthquake [35] clarified that relations with neighborhood and friends after moving to post-earthquake 
houses tended to be lost in the large scale and high-rise living environment. The victim of the nuclear station accidents by the Great East Japan Earthquake lost the community they had had before the disaster due to evacuation, and forced to live in temporary houses for an exceptionally long period. Furthermore, they lost the community among the residents of temporary houses, which was newly formed during 6 years in their evacuation life after they move to the postearthquake houses. Although several years have passed since the occurrence of the disaster, the mental health of the late middle age males who evacuated for a long period has been worsened by the nuclear disaster. Relocation to the post-earthquake houses is considered as a factor for it. Most of the past investigations on the mental health of disaster victims were performed at a relatively early stage and $80 \%$ of them were performed within 1 year after the disasters [36]. In Japan, such investigations came to be performed often since the Great Hanshin-Awaji Earthquake. However, about a half of them was performed within one year after the disaster and $40 \%$ of them were done within 1 - 4 years while on the other hand only few of them were performed over 4 years after the disaster [37]. It has been proved that feeling of rest obtained by sleep strongly influences mental health [38] and therefore it is important to keep observing the course of sleep and stress of the victims.

\section{Conclusion}

As for the results of investigation on sleep and stress of late middle age males who were forced to live in shelters for a long period due to the nuclear disaster, comparison between the life in temporary houses and post-earthquake houses has revealed that there were no significant differences in objective sleep state and saliva stress biomarkers though the subjective sleep and stress was worsened after moving to the post-earthquake houses.

\section{Limitations of the Study}

There have been no studies that measured objective sleep and stress of late middle age males who assumes an important role for the reconstruction. The number of subjects was insufficient for this investigation and therefore there is a limitation in terms of generalization of the results. The authors are going to investigate the course of the subjects continuously in the future, and clarify the sleep and stress of late middle age males living in shelters for a long period due to the nuclear disaster by investigating individual experiences through interviews and integrating qualitative data and quantitative data, so as to seek for methods to support them.

\section{Acknowledgements}

The authors sincerely thank the residents for their cooperation for this investigation. This study was conducted with the aid of 2015 Grant-in-Aid Scientific Research (C) (No. 15K11929). 


\section{References}

[1] Reconstruction Information Portal Site of Fukushima Reconstruction Station (2017) Flash Report on Damage Caused by the Great East Japan Earthquake in 2011 (Report No. 1710).

http://www.pref.fukushima.lg.jp/uploaded/life/298487_717515_misc.pdf

[2] Fukushima Prefecture (2017) Progress of Emergency Temporary Houses, Leased Houses and Public Houses in Fukushima.

https://www.pref.fukushima.lg.jp/uploaded/life/298708_718141_misc.pdf

[3] Reconstruction Agency (2017) Number of Deaths Related to the Great East Japan Earthquake.

http://www.reconstruction.go.jp/topics/main-cat2/sub-cat2-6/20170630_kanrenshi. pdf

[4] Office for Policy of Suicide Prevention of Ministry of Health, Labour and Welfare (2017) The Number of Suicides Related to the Great East Japan Earthquake (2016). http://www.mhlw.go.jp/file/06-Seisakujouhou-12200000-Shakaiengokyokushougaih okenfukushibu/h28kakutei_5.pdf

[5] Norris, F.H., Matthew, J., Friedman, M.J., Watson, P.J., Byrne, C.M., Diaz, E. and Kaniasty, K. (2002) 60,000 Disaster Victims Speak; Part I. Anempirical Review of the Empirical Literature, 1981-2001. Psychiatry, 65, 207-239. https://doi.org/10.1521/psyc.65.3.207.20173

[6] Fujii, S., Oe, M. and Maeda, S. (2014) Review of Long-Term Influence of Human Disasters and Natural Disasters. Traumatic Stress, 12, 89-98.

[7] Tsuji, I. (2013) Grant-in-Aid Scientific Research (Health and Safety/Risk Management Measures Total Research) Investigation on Health Conditions of the Great East Japan Earthquake Victims in Miyagi. 2012 General/Sharing Research Report (Study Representative: Ichiro Tsuji).

[8] Hayashi, K. (2012) 2011 Grant-in-Aid Scientific Research. General/Sharing Research Report. Investigation on Health Conditions of the Great East Japan Earthquake Victims (Study Representative: Kenji Hayashi).

[9] Tubokura, M., Takita, M., Matsumura, T., Hara, K., Tanimoto, T., Kobayashi, K., et al. (2013) Changes in Metabolic Profiles after the Great East Japan Earthquake: A Retrospective Observational Study. BMC Public Health, 13, 267.

https://doi.org/10.1186/1471-2458-13-267

[10] Radiology Citizen Health Management Center, Fukushima Global Medical Science Center of Fukushima Medical University (2015) 2014 Summary of Mental Health and Life Habit Research Result. https://www.pref.fukushima.lg.jp/uploaded/attachment/167948.pdf

[11] Namie Town (2014) Refugee Citizen Health Management Measure-Current Situations of Refugee Citizen Three Yeas after the Nuclear Accident-“Health White Paper".

[12] Watanabe, M., Kikuchi, H., Tanaka, K. and Takahashi, M. (2010) Association of Short Sleep Duration with Weight Gain and Obesity at 1-Year Follow-Up: A Large-Scale Prospective Study. Sleep, 33, 161-167. https://doi.org/10.1093/sleep/33.2.161

[13] Kim, C.W., Choi, M.K., Im, H.J., Kim, O.H., Lee, H.J., Song, J., et al. (2012) Weekend Catch-Up Sleep Is Associated with Decreased Risk of Being Overweight among Fifth-Grade Students with Short Sleep Duration. Journal of Sleep Research, 21, 546 551. https://doi.org/10.1111/j.1365-2869.2012.01013.x 
[14] Chaput, J.P., Despres, J.P., Bouchard, C., Astrup, A. and Tremblay, A. (2009) Sleep Duration as a Risk Factor for the Development of Type 2 Diabetes or 19 Impaired Glucose Tolerance: Analyses of the Quebec Family Study. Sleep Medicine, 10, 919924. https://doi.org/10.1016/j.sleep.2008.09.016

[15] Troxel, W.M., Buysse, D., Matthews, K.A. and Reis, S.E. (2010) Sleep Symptoms Predict the Development of the Metabolic Syndrome. Sleep, 33, 1633-1640. https://doi.org/10.1093/sleep/33.12.1633

[16] Buysse, D.J., Angst, J., Gamma, A., Ajdacic, V., Eich, D. and Rossler, W. (2008) Prevalence, Course, and Comorbidity of Insomnia and Depression in Young Adults. Sleep, 31, 473-480. https://doi.org/10.1093/sleep/31.4.473

[17] Girschik, J.J., Fritschi, L., Heyworth, J. and Wates, F. (2012) Validation of SelfReported Sleep against Actigraph. Journal of Epidemiology, 22, 462-468. https://doi.org/10.2188/jea.JE20120012

[18] Yoshiyuki, T. and Shigeru, C. (2005) Usability of Actigraph for Sleep Disorders. Modern Physician, 25, 23-28.

[19] Cole, R.J., Kripke, D.F., Gruen, W., Mullaney, D.J. and Glillin, J.C. (1992) Automatic Sleep/Wake Identification from Wrist Activity. Sleep, 15, 461-469. https://doi.org/10.1093/sleep/15.5.461

[20] Doi, Y., Minowa, M., Uchiyama, M., Okawa, M., Kim, K., Shibui, K. and Kamei, Y. (2000) Psychometric Assessment of Subjective Sleep Quality using the Japanese Version of the Pittsburgh Sleep Quality Index (PSQI-J) in Psychiatric Disordered and Control Subjects. Psychiatry Research, 97, 165-172. https://doi.org/10.1016/S0165-1781(00)00232-8

[21] Yasuaki, N. and Ikuo, D. (1985) GHQ Mental Health Questionnaire Handbook. Japanese Edition, Nihon Bunka Kagakusha Co., Ltd., Tokyo.

[22] Masaki, Y. (2007) Stress Measurement with Saliva Marker. Nippon Yakurigaku Zasshi, 129, 80-84. https://doi.org/10.1254/fpj.129.80

[23] Sousuke, A. (2003) Evaluation of Mental Stress with Amylase and Cortisol in Saliva. Journal of the Japanese Society of Oral Diagnosis/ Oral Medicine, 16, 362-370.

[24] Nakane, H., Asami, O., Yamada, Y. and Yanaihara, N. (2001) Chromogranin A in Saliva as a Mental Stress Marker. Clinical Examination, 45, 284-287.

[25] Bosch, J.A., Ring, C., de Geus, E.J., Veerman, E.C. and Amerongen, A.V. (2002) Stress and Secretory Immunity. International Review of Neurobiology, 52, 213-253. https://doi.org/10.1016/S0074-7742(02)52011-0

[26] Ministry of Education, Culture, Sports, Science and Technology, Ministry of Health, Labour and Welfare (2014) Ethics Guideline for the Medical Studies Targeting Human.

http://www.mhlw.go.jp/file/06-Seisakujouhou-10600000-Daijinkanboukouseikagak uka/0000153339.pdf

[27] Keiji, I. (2006) Ethical Guideline for Investigative Research for Disaster Victims, Understanding and Care of Psychic Trauma. 2nd Edition, Jiho Inc., Tokyo, 308-311.

[28] Japan Society for Disaster Information Studies (2011) Investigation Guideline for the Great East Japan Earthquake.

http://www.jasdis.gr.jp/_userdata/06chousa/main_data/07re-guideline.pdf

[29] Ohayon, M.M., Carskadon, M.A., Guilleminault, C. and Vitiello, M.V. (2004) Meta-Analysis of Quantitative Sleep Parameters from Childhood to Old Age in Healthy Individuals: Developing Normative Sleep Values across the Human Lifespan. Sleep, 27, 1255-1273. https://doi.org/10.1093/sleep/27.7.1255 
[30] Iijima, Y., Sumiyoshi, Y., Aono, F. and Miyano, M. (1996) Study on Life in Emergency Temporary House: Hokudan-cho in the South Hyogo Earthquake in 1995. Institute of Social Safety Science, 235-242.

[31] Tsuji, I. (2017) Grant-in-Aid Scientific Research (Health and Safety/Risk Management Measures Total Research) Investigation on Health Conditions of the Great East Japan Earthquake Victims in Miyagi. 2012 General/Sharing Research Report, Study Representative: Ichiro Tsuji.

[32] Ikeda, K., Yamamoto, Y., Nakano, C., Kay, K.N., Ono, K., Hosomi, A., et al. (2001) Health and Life of Aged Residents of the Post-Earthquake Houses-From the 4th Follow-Up Study. Bulletin of Kobe City Junior College of Nursing, 20, 97-102.

[33] Kinoshita, H., Ota, Y., Nakane, H., Ichinose, H., Kurotaki, N. and Ozawa, H. (2012) Mental Problems of the Victims of the Mt. Fugen in Unzen Eruptions Observed Long Time after the Disaster-From the Investigation Performed 13 Years after the Disaster. Clinical Psychiatry, 41, 1293-1298.

[34] Fujimori, T. (1998) Prolonged Problems of Mental Health and Natural Disaster-Victim of the South-West off Hokkaido Earthquake. Personality Psychology Study, 7, 11-21.

[35] Shiozaki, Y., Tanaka, M., Meguro, E. and Hotta, Y. (2007) Variation in the Houseroom Characteristics and Social "Isolation" in the Families Living in Post-Disaster Reconstruction Public Houses-Through the Case of the Great Hanshin-Awaji Earthquake. Proceedings of Architectural Institute of Japan, 611, 109-116.

[36] Norris, F.H., Galea, S., Friedman, M.J. and Watoson, P.J. (2006) Psychological Consequences of Methods for Disaster Mental Health Research. Guilford Press, New York, 20-42.

[37] Toyomi, G., Fujii, S. and Kato, Y. (2007) The Influence of Major Disaster on Mental Health of the Community; Mental Health, Behaviors and Trauma of Kobe City Citizens 11 Years after the Earthquake Disaster. Psychological Trauma Study, 3, 1-24.

[38] Walsh, J.K., Coulouvrat, C., Hajak, G., Lakoma, M.D., Petukhova, M., Roth, T., et al. (2011) Nighttime Insomnia Symptoms and Perceived Health in the America Insomnia Survey (AIS). Sleep, 34, 997-1011. https://doi.org/10.5665/SLEEP.1150 